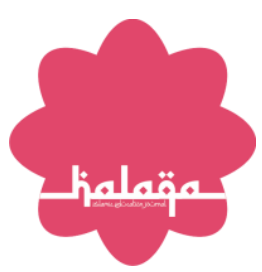

OPEN ACCESS

ISSN 2503-5045 (online)

ISSN 1412-9302 (print)

Edited by:

Eni Fariyatul Fahyuni

Reviewedby:

Nurdyansyah

*Correspondence:

M. Islam

m.islamsidoarji@gmail.com

Received: 1 Maret 2021

Accepted:6 Maret 2021

Published:20 Maret 2021

Citation:

M. Islam (2021) Management of Islamic Boarding School Curriculum Integration in Improving the Quality of Madrasah Education. Halaqa: Islamic Education Journal.

5:1.

\title{
Management of Islamic Boarding School Curriculum Integration in Improving the Quality of Madrasah Education
}

\section{Manajemen Integrasi Kurikulum Pesantren Dalam Meningkatkan Mutu Pendidikan Madrasah}

\author{
M. Islam* \\ Balai Diklat Keagamaan Surabaya, Indonesia
}

The integration of the pesantren curriculum in formal educational institutions has not been widely carried out. Although there are partial characteristics and have not been managed properly. The integrated management of the pesantren curriculum in madrasah can be used as an alternative in strengthening the uniqueness of madrasas, especially religious material. The results of this study indicate that the integration of the pesantren curriculum into madrasah can improve understanding of religious material more thoroughly and deeply. Classical book studies, which have been disinterested by young people, can be revitalized through the integration of the pesantren curriculum in madrasas. For that, it is necessary to plan, organize, implement, and evaluate carefully to implement integrated management of the pesantren curriculum in the madrasah curriculum. Structurally, the curriculum can be included in local content.

Keywords: Integration, Curriculum, Islamic Boarding School

Integrasi kurikulum pesantren dalam lembaga pendidikan formal masih belum banyak dilakukan. Meskipun ada sifatnya masih parsial dan belum dimanage dengan baik. Manajemen integrasi kurikulum pesantren di madrasah dapat dijadikan alternatif dalam penguatan kekhasan madrasah, terutama materi keagamaan. Hasil kajian ini menunjukkan, integrasi kurikulum pesantren ke madrasah dapat meningkatkan pemahaman materi agama dengan lebih matang serta mendalam. Kajian kitab klasik yang selama ini mulai tidak diminati kalangan muda dapat direvitalisasi melalui integrasi kurikulum pesantren di madrasah. Untuk itu, perlu perencanaan, pengorganisasian, pelaksanaan, dan evaluasi yang matang untuk menerapkan manajemen integrasi kurikulum pesantren dalam kurikulum madrasah. Secara struktur kurikulum dapat dimasukkan dalam muatan local.

Kata Kunci: Integrasi, Kurikulum, Pesantren 


\section{PENDAHULUAN}

Pendidikan merupakan elemen penting dalam pembangunan bangsa. Dalam sistem pendidikan terdapat komponen kurikulum yang sangat strategis untuk mewujudkan arah pendidikan nasional. Oleh karena itu, kurikulum memiliki posisi sentral dalam penyelenggaraan kegiatan pendidikan untuk mencapai tujuan pendidikan nasional. Tujuan tertentu ini meliputi tujuan pendidikan nasional serta kesesuaian dengan kekhasan, kondisi dan potensi daerah. Selain itu kurikulum juga menyesuaikan tujuan satuan pendidikan, kompetensi lulusan pada satuan pendidikan, dan peserta didik. Kurikulum disusun oleh satuan pendidikan yang memungkinkan penyesuaian program pendidikan dengan kebutuhan dan potensi yang ada di daerah. Selanjutnya, konsep ini disebut dengan kurikulum lokal.

Kurikulum dalam dimensi proses adalah realisasi ide serta menjadi rancangan dalam proses pembelajaran. Sedangkan tenaga pendidik adalah tenaga utama yang mengembangkan ide dan rancangan tersebut dalam proses pembelajaran. Pemahaman tenaga pendidik tentang kurikulum akan mendukung keberhasilan implementasi kurikulum. Hilda Taba, (1962) mendefinisikan kurikulum berisi pernyataan tujuan dan arah spesifik yang mengindikasikan sejumlah seleksi dan isi organisasi yang tentunya berimplikasi dan menifestasi pada pola belajar mengajar. Di dalamnya juga meliputi evaluasi hasil pembelajaran. Pengembangan kurikulum seharusnya didasarkan kepada standar nasional pendidikan sehingga diharapkan terjamin pencapaian tujuan pendidikan nasional. Standar nasional pendidikan terdiri atas standar isi, proses, kompetensi lulusan, tenaga kependidikan, sarana dan prasarana, pengelolaan, pembiayaan, dan penilaian pendidikan. Dari kedelapan standar nasional pendidikan tersebut, standar kompetensi lulusan, standar isi, standar proses, dan standar penilaian merupakan acuan utama untuk mengembangkan kurikulum tingkat satuan pendidikan.

Dalam UU No. 20/2003 tentang Sistem Pendidikan Nasional, dinyatakan bahwa pendidikan nasional berfungsi untuk mengembangkan kemampuan dan membentuk watak serta peradaban bangsa yang bermartabat dalam rangka mencerdaskan kehidupan bangsa, bertujuan untuk mengembangkan potensi peserta didik agar menjadi manusia yang beriman dan bertakwa kepada Tuhan Yang Maha Esa, berakhlak mulia, sehat, berilmu, cakap, kreatif, mandiri, dan menjadi warga negara yang demokratis serta bertanggung jawab. Inilah yang harus dicapai melalui kurikulum inetgratif. Kurikulum selama ini terlalu berorientasi pada pengembangan otak kiri (kognitif) dan kurang memperhatikan pengembangan otak kanan (afektif, empati, dan rasa). Proses belajar juga berlangsung secara pasif dan kaku sehingga menjadi tidak menyenangkan bagi anak. Sebagai contoh, salah satu mata pelajaran yang berkaitan dengan pembelajaran akhlak (seperti budi pekerti dan agama) ternyata pada prakteknya lebih menekankan pada aspek otak kiri (hafalan, atau hanya sekedar tahu). Semuanya ini telah membuat suasana belajar monoton/kaku, membosankan anak sehingga anak menjadi tidak kreatif. Padahal, pembelajaran seharusnya dilakukan secara aktif, sistematis dan berkesinambungan, bermakna serta menyenangkan. Pembelajaran dapat diibaratkan sebagai proses pembentukan seseorang menjadi pribadi yang baik dan bijksana (smart and good) yang memerlukan latihan secara terus-menerus agar menjadi kokoh dan kuat.

Dalam konteks ini, manajemen kurikulum dalam upaya integrasi kurikulum madrasah dan kurikulum pesantren menjadi isu penting dalam lembaga pendidikan Islam. Kurikulum madrasah yang disesuaikan dengan kurikulum pesantren dapat menjadi alternatif konsep tersendiri. Integrasi kurikulum dapat dilakukan untuk mewujudkan integrasi ilmu umum dalam perspektif kurikulum nasional dan ilmu agama dalam perspektif dunia pesantren. Sebenarnya, hal ini sebagai bagian dari upaya konsolidasi ilmu untuk mewujudkan pendidikan tanpa dikotomi ilmu pengetahuan seperti masa kejayaan pendidikan Islam di abad keemasan, yaitu abad VII dan VIII masehi.

Sementara itu, manajemen integrasi kurikulum masih belum diimplementasikan dengan baik di madrasah berbasis pesantren. Kurikulum pesantren yang selama ini memberi konten pendidikan agama, pengalaman pendidikan moral, sekolah dan pendidikan umum, serta keterampilan perlu dikelola dengan manajemen integratif. Keberadaan madrasah di lingkungan pesantren sebenarnya menerapkan kurikulum yang memadukan Sistem Pendidikan Nasional, Pesantren, Kecakapan Hidup dan ketrampilan berbahasa Global yaitu Bahasa Inggris dan Arab serta memperkuat pendidikan akhlak Islami. Selain menjadi tuntutan masyarakat, konsep integrasi kurikulum ini juga menjadi kebutuhan administratif di madrasah berbasis pesantren. Konsep pendidikan yang holistik dan integratif Antara ilmu umum dengan ilmu agama dikembangkan di semua madrasah berbasis pesantren yang akhir-akhir ini menjadi pilihan masyarakat. Latar belakang inilah yang menjadikan tulisan ini penting dilakukan.

\section{HASIL DAN PEMBAHASAN}

\section{Konsep Manajemen Kurikulum}

Manajemen adalah ilmu pengelolaan dalam sebuah organisasi dengan tujuan untuk mencapai tujuan organisasi secara efektif dan efesien. Dengan kata lain manajemen adalah "tindakan untuk mencapai suatu tujuan melalui usaha-usaha orang lain. Aktivitas manajemen di sekolah dapat tergambar dari tindakan kepala sekolah dalam mengatur, mendayagunakan, dan melakukan pembinaan terhadap tenaga pendidik-tenaga pendidik, karyawan, serta kurikulum untuk mencapai tujuan sekolah". Burhanuddin (2002) Setidaknya dalam ilmu manajemen ada tiga dimensi yang harus diperhatikan yakni (1) suatu gugus subsatnsi problem tertentu, (2) proses kegiatan manajemen, dan (3) perilaku manusia dan kepeminpinan dalam organisasi". Suhertian (1985) Implementasi dari beberapa pengertian tentang manajemen di atas adalah bahwa manajemen merupakan serangkaian kegiatan yang menyangkut perencanaan, mengorganisasikan, menggerakkan, mengendalikan dan mengembangkan terhadap segala upaya dalam mengatur dan 
mendayagunakan semua sumberdaya yang dimiliki guna mencapai tujuan oerganisasi yang telah dicanangkan.

Manajemen ketika dipandang sebagai gugusan substansi problem tertentu maka yang dibicarakan adalah mengenai pengelolaan proses belajar mengajar, kesiswaan, ketenagaan, peralatan (media pelajaran), keuangan, pemeliharaan gedung dan perabot sekolah, dan pengelolaan hubungan sekolah dengan masyarakat. Sedangkan manajemen dilihat dari sudut pandang proses kegiatan manajemen berarti bahwa dalam pencapaian tujuan suatu organisasi dilakukan dengan menerapkan fungsi-fungsi manajemen seperti; perencanaan, pengorganisasian, pengarahan dan stimulasi, pengkoordinasian, pengawasan dan evaluasi, serta pengambilan keputusan. Dimensi yang terakhir adalah manajemen pendidikan sebagai tindakan kepemimpinan dan perilaku manusia. Dengan demikian, kedudukan manajemen dalam tataran mikro (sekolah) berkontribusi terhadap keberhasilan suatu sekolah dan dalam memahmi manajemen pendidikan kita seharusnya tidak terpaku pada suatu definisi tertentu karena manajemen itu bukan dimensi tunggal.

Manajemen dalam konteks pengelolaan sekolah tidak hanya meliputi aspek manusia dan material, tetapi juga termasuk aspek kurikulum yang menjadi bagian tidak terpisahkan di dalam mencapai tujuan sekolah. Manajemen kurikulum menjadi kegiatan penting dalam pengelolaan sekolah karena output sekolah dimuat dalam desain pengembangan kurikulum. Mengingat kurikulum merupakan seperangkat pengalaman bsik di dalam maupun di luar sekolah, maka perlu manajemen kurikulum. Kegiatan manajemen kurikulum dilaksanakan secara bersama di bawah kordinasi kepala sekolah. Dengan demikian manajemen kurikulum adalah penerapan fungsi-fungsi manajemen dalam pengelolaan kurikulum pendidikan di lembaga pendidikan dalam rangka untuk mewujudkan tujuan pendidikan dan pembelajaran.

Dalam konteks manajemen kurikulum langkah ini merupakan tahapan untuk menentukan tujuan kurikulum di sekolah. Dalam penentuan tujuan kurikulum, pengelola sekolah merujuk pada beberapa aspek pendidikan termasuk paradigm pendidikan lembaga pendidikan. Sebagai contoh perencanaan yang baik dalam kurikulum yang diterapkan pada SNP plus X adaptif Cambridge. Melalui kurikulum ini, siswa dapat menempuh ujian Cambridge hingga sukses pada UN (Ujian Nasional) maupun OSN (Olimpiade Sains Nasional) dengan cara melakukan pembedahan SKL sejak tingkat awal, yaitu kelas X. Siswa dari sekolah lain yang ingin mengikuti program tersebut juga diikutkan dalam ujian sertifikat Cambridge. Pelaksanaan kurikulum SNP plus X adaptif Cambridge juga diharuskan sesuai dengan silabus maupun rencana pelaksanaan pembelajaran yang telah disusun melalui workshop. Adapun evaluasi kurikulum terkait program unggulan bertujuan untuk mengukur tingkat kesuksesan peserta didik melalui evaluasi formatif maupun sumatif. Sudarsono (2016)

Pengorganisasian diartikan sebagai kegiatan membagi tugas-tugas kepada orang yang terlibat dalam kerja sama pendidikan. Karena tugas-tugas ini demikian banyak dan tidak dapat diselesaikan oleh satu orang saja, maka tugastugas ini dibagikan untuk dikerjakan masing-masing anggota organisasi. Dalam menejemen kurikulum pengorganisasian meliputi organisasi materi kurikulum atau isi kurikulum, yang terdiri dari mata pelajaran, kegiatan pembelajaran, serta program pembelajaran. Kurikulum tidak hanya berisi mata pelajaran, tetapi juga program pembelajaran. Fungsi-fungsi manajemen pendidikan mempunyai peran penting dalam mempermudah pelaksanaan kurikulum sekaligus dalam upaya integrasi ilmu. Lembaga pendidikan yang memiliki sumber daya berkualitas tetapi tidak diterapkan fungsi manajemen maka implementasi kurikulum tidak bisa maksimal.

Contohnya pada kurukulum 2013, dimana keberhasilan implementasi kurikulum ditentukan oleh seberapa berkualitas pelatihan yang telah dilaksanakan. Kualitas pelatihan mencakup berbagai hal seperti kualitas materi, ketepatan metode dan alokasi pelatihan, hingga profesionalisme pelatih. Namun, rendahnya kualitas sarana dan prasarana pembelajaran, rumitnya model assessment siswa bagi guru, minimnya pelatihan kurikulum, kurangnya buku pegangan bagi guru dan siswa, serta tidak adanya evaluasi dan monitoring dari pemerintah menjadi permasalahan utama dalam implementasi kurikulum 2013. Sumarni (2017) Kerangka dasar pengembangan kurikulum minimal meliputi perencanaan, implementasi, dan evaluasi kurikulum. Ketiganya harus dilaksanakan oleh "manajer" sekolah dalam melakukan manajamen kurikulum. Marno (2008) Dengan demikian setiap fungsi manajemen perlu diterapkan dalam manajemen kurikulum dalam upaya integrasi ilmu untuk tujuan pendidikan berbasis ilmu pengetahuan yang holisticinterkonektif. Terjadi perpaduan ilmu agama dan ilmu umum di lembaga pendidikan Islam.

\section{Kurikulum dan Konsep Integrasi IImu}

Pembahasan tentang integrasi ilmu agama dan sains telah berlangsung berabad-abad lamanya. Para ilmuan Islam pun telah melakukan konsolidasi integrasi ilmu dengan berbagai forum ilmiah. Dengan sebuah konsep bahwa ummat Islam akan maju dapat menandingi peradaban barat apabila mampu menstransformasikan dan menyerap secara aktual terhadap ilmu pengetahuan dalam dengan intergrasi wahyu serta mampu memahami wahyu dalam mengembangkan ilmu pengetahuan. Premis-premis normatif dalam al-Qur'an dapat dirumuskan menjadi teori-teori empiris dan rasional. Struktur transendental al-Qur'an adalah sebuah ide normatif dan filosofis yang dapat dirumuskan menjadi paradigma teoretis. Setiap ayat al-Qur'an akan menjadi kerangka bagi pertumbuhan ilmu pengetahuan empiris dan rasional yang orisinal, dalam arti sesuai dengan kebutuhan pragmatis umat manusia sebagai khalifah di bumi. Itulah sebabnya pengembangan teori-teori ilmu pengetahuan Islam perlu dikuatkan melalui integrasi ilmu. Syaekhuddin (2014)

M. Quraish Shihab mengatakan, membahas hubungan AlQuran dan ilmu pengetahuan bukan dinilai dengan banyaknya cabang-cabang ilmu pengetahuan yang tersimpul di 
dalamnya, bukan pula dengan menunjukkan kebenaran teoriteori ilmiah. Tetapi pembahasan hendaknya diletakkan pada proporsi yang lebih tepat sesuai dengan kemurnian dan kesucian al-Qur'an dan sesuai pula dengan logika ilmu pengetahuan itu sendiri. Azra (2005) Paparan di atas dapat dipahami bahwa konsep integrasi ilmu dalam khazanah ilmu pengetahuan adalah untuk menyatukan ilmu pengetahuan dalam perspektif universal. Wahyu menjadi landasan utama yang secara integratif menjadi sumber nilai dalam pengembangan ilmu pengetahuan. Definisi ilmiah, konsep ilmiah, teori ilmiah, serta ilmu pengetahuan dibangun dengan landasan serta perspektif universal. Kebenaran ilmu berlaku secara universal dengan merujuk pada nilai ketuhanan. Logika manusia diselaraskan dengan kebenaran wahyu yang bersifat transenden dalam kehidupan manusia.

Dengan demikian mengintegrasikan ilmu-ilmu keislaman ke dalam ilmu-ilmu umum sebaiknya mengacu kepada perspektif ontologis, epistemologis dan aksiologis. Dari perspektif ontologis, bahwa ilmu itu pada hakekatnya merupakan pemahaman yang timbul dari hasil studi yang mendalam, sistematis, obyektif dan menyeluruh tentang ayatayat Allah swt, baik berupa ayat-ayat qauliyyah yang terhimpun di dalam al-Qur'an maupun ayat-ayat kauniyah yang terhampar dijagat alam raya ini. Karena keterbatasan kemampuan manusia untuk mengkaji ayat-ayat tersebut, maka hasil kajian / pemikiran manusia tersebut harus dipahami atau diterima sebagai pengetahuan yang relatif kebenarannya, dan pengetahuan yang memiliki kebenaran mutlak hanya dimiliki oleh Allah SWT. Sementara itu, dalam perspektif epistemologi ilmu pengetahuan dan teknologi diperoleh melalui usaha yang sungguh-sungguh dengan menggunakan instrumen penglihatan, pendengaran dan hati yang diciptakan Allah SWT terhadap hukum-hukum alam dan sosial (sunnatullah). Karena itu tidak menafikan Tuhan sebagai sumber dari segala realitas termasuk ilmu pengetahuan dan teknologi.

Dari perspektif aksiologi, bahwa ilmu pengetahuan dan teknologi harus diarahkan kepada pemberian manfaat dan pemenuhan kebutuhan hidup umat manusia. Bukan sebaliknya, ilmu pengetahuan dan teknologi digunakan untuk menghancurkan kehidupan manusia. Perlu disadari bahwa ilmu pengetahuan dan teknologi adalah bagian dari ayat-ayat Allah dan merupakan amanat bagi pemiliknya yang nantinya akan dimintai pertanggung jawaban di sisi-Nya. Nilai manfaat ilmu pengetahuan menjadi indikator utama dari nilai universalitas ilmu pengetahuan. Pemenuhan atas segala kebutuhan manusia di dunia seharusnya dapat dipenuhi dengan adanya ilmu pengetahuan. Ketika ilmu memberikan manfaat bagi kehidupan manusia maka disitulah konsep aksiologi dalam pengembangan ilmu pengetahuan telah teralisasi. Hadirnya ilmu berarti untuk memudahkan manusia dalam menjalankan kehidupan di dunia.

Perumusan teori ilmu pengetahuan yang didasarkan kepada al-Qur'an sebagai suatu paradigma. Upaya yang dilakukan adalah objektifikasi. Islam dijadikan sebagai suatu ilmu yang objektif, sehingga ajaran Islam yang terkandung dalam al-Qur'an dapat dirasakan oleh seluruh alam (rahmatan lil 'alamin), tidak hanya untuk umat Islam tapi non-muslim juga bisa merasakan hasil dari objektivikasi ajaran Islam. Dalam konteks pembelajaran sekalipun, Al-Qur'an dapat dijadikan sebagai sebuah paradigma untuk menjalankan pembelajaran dengan upaya: a) memetakan konsep keilmuan umum dan keilmuan agama; b) memadukan konsep keilmuan umum dan keilmuan agama; c) mengelaborasi ayat-ayat alQuran yang relevan secara saintifik. Husniyatus (2014) Kemaslahatan ilmu diperuntukkan untuk semua manusia secara universal, sesuai nilai utuh ilmu itu sendiri.

\section{Model Integrasi IImu}

Respon para ilmuwan Islam dalam menanggapi integrasi ilmu memunculkan berbagai model integrasi sesuai pendekatan serta perspektif setiap cendekiawan muslim dalam mengembangkan keilmjuan Islam. Ada tipologi yang beragam dalam integrasi ilmu yang telah dihasilkan para ilmuwan muslim. Dalam pandangan Azyumardi Azra, ada tiga tipologi respon cendekiawan muslim berkaitan dengan hubungan antara keilmuan agama dengan keilmuan umum. Pertama: Restorasionis, yang mengatakan bahwa ilmu yang bermanfaat dan dibutuhkan adalah praktik agama (ibadah). Cendekiawan yang berpendapat seperti ini adalah Ibrahim Musa (w. 1398 M) dari Andalusia. Ibnu Taymiah, mengatakan bahwa ilmu itu hanya pengetahuan yang berasal dari nabi saja. Begitu juga Abu Al-A'la Maududi, pemimpin jamaat al-Islam Pakistan, mengatakan ilmu-ilmu dari barat, geografi, fisika, kimia, biologi, zoologi, geologi dan ilmu ekonomi adalah sumber kesesatan karena tanpa rujukan kepada Allah SWT dan Nabi Muhammad Saw.

Kedua: Rekonstruksionis interprestasi agama untuk memperbaiki hubungan peradaban modern dengan Islam. Mereka mengatakan bahwa Islam pada masa Nabi Muhammad dan sahabat sangat revolutif, progresif, dan rasionalis. Sayyid Ahmad Khan (w. 1898 M) mengatakan firman Tuhan dan kebenaran ilmiah adalah sama-sama benar. Jamal al-Din al-Afgani menyatakan bahwa Islam memiliki semangat ilmiah. Ketiga: Reintegrasi, merupakan rekonstruksi ilmu-ilmu yang berasal dari al-ayah alqur'aniyah dan yang berasal dari al-ayah al-kawniyah berarti kembali kepada kesatuan transsendental semua ilmu pengetahuan.

Dalam pandangan ini, model integrasi ilmu adalah menjadikan al-Qur'an dan Sunnah sebagai grand theory pengetahuan. Sehingga ayat-ayat qauliyah dan qauniyah dapat dipakai dalam upaya integrasi ilmu. Integrasi yang dimaksud di sini adalah berkaitan dengan usaha memadukan keilmuan umum dengan Islam tanpa harus menghilangkan keunikankeunikan antara dua keilmuan tersebut. Sementara itu, Amin Abdullah, mengembangkan model integratif-interkonektif dalam upaya untuk menjadikan sebuah keterhubungan antara keilmuan agama dan keilmuan umum. Muara dari pendekatan 
integratif-interkonektif menjadikan keilmuan mengalami proses obyektivikasi dimana keilmuan tersebut dirasakan oleh orang non Islam sebagai sesuatu yang natural (sewajarnya), tidak sebagai perbuatan keagamaan. Sekalipun demikian, dari sisi yang mempunyai perbuatan, bisa tetap menganggapnya sebagai perbuatan keagamaan, termasuk amal, sehingga Islam dapat menjadi rahmat bagi semua orang. Abdullah (2006)

Contoh konkrit dari proses objektivikasi keilmuan Islam adalah Ekonomi Syariah yang prakteknya dan teori-teorinya berasal dari wahyu Tuhan. Islam menyediakan etika dalam perilaku ekonomi antara lain; bagi hasil (al-Mudarabah) dan kerja sama (al-Musyarakah). Di sini Islam mengalami objektivitas dimana etika agama menjadi ilmu yang bermanfaat bagi seluruh manusia, baik muslim maupun non muslim, bahkan arti agama sekalipun. Kedepan, pola kerja keilmuan yang integralistik dengan basis moralitas keagamaan yang humanistik dituntut dapat memasuki wilayah-wilayah yang lebih luas seperti: psikologi, sosiologi, antropologi, kesehatan, teknologi, ekonomi, politik, hubungan internasional, hukum dan peradilan dan seterusnya. Abdullah (2006)

Pendekatan integrasi interkoneksi lebih bersifat menghargai keilmuan umum yang sudah ada, karena keilmuan umum juga telah memiliki basis epistemologi, ontologi dan aksiologi yang mapan, sambil mencari letak persamaan, baik metode pendekatan (approach) dan metode berpikir (procedure) antar keilmuan dan memasukkan nilai-nilai keilmuan Islam ke dalamnya, sehingga keilmuan umum dan agama dapat saling bekerja sama tanpa saling mengalahkan. Dalam model ini, kompromi keilmuan akan terjadi dan saling melengkapi diantara kedua basis keilmuan. Ilmu pengetahuan umum akan mendapat sentuhan nilai dan akan memiliki makna yang lebih, sedangkan ilmu agama akan mendapatkan obyektivikasi dari khazanah yang telah dikembangkan ilmu umum. Model integrasi ilmu inilah yang dinilai sesuai dengan konsep integrasi ilmu oleh para pemikir Islam.

Terdapat beberapa model integrasi ilmu yang dihasilkan para ilmuan Islam. Model integrasi ini dikembangkan sesuai dengan perspektif masing-masing cendekiawan, bahkan terjadi secara seporadis. Secara lebih jelas dipaparkan dalam bagan di bawah ini sebagaimana dikembangkan Huzni Thoyyar (2014).

\section{[Table 1 about here.]}

Model integrasi yang dikembangkan para cendekiawan muslim ini ada yang memiliki kesamaan konsep serta ada yang memiliki perbedaan konsep. Sebagian memandang harus ada islamisasi ilmu, sehingga semua ilmu merujuk pada nilai agama yang bersumber dari wahyu. Sistem nilai dalam ilmu pengetahuan perlu dikuatkan agar lebih bermakna secara universal. Sementara itu, sebagian ilmuwan konsepnya tidak harus dilakukan Islamisasi ilmu, tetapi wahyu dan nilai Islam dijadikan landasan filosofis dalam pengembangan ilmu pengetahuan baik dari aspek epistimologi, ontologi, serta aksiologi. Dengan demikian model integrasi ilmu tidak terjebak dalam perdebatan tentang ilmu Islam dan ilmu umum. Berbagai model integrasi ini juga telah berkembang di Indonesia. Sejumlah lembaga pendidikan Islam telah menggagas integrasi ilmu dengan memasukkan konsep integrasi dalam kurikulum yang dikembangkan di sekolah. Sekolah Islam terpadu adalah satu diantara lembaga pendidikan Islam yang berusaha melakukan integrasi ilmu. Bahkan lebih umum lagi, madrasah adalah lembaga yang juga menerapkan integrasi ilmu. Pada mulanya madrasah hanya merupakan lembaga pendidikan Islam yang hanya mengajarkan mata pelajaran agama. Dalam perkembangannya, madrasah diberbagai negara telah melakukan prosses intergrasi dengan mengajarkan mata pelajaran agama dan mata pelajaran umum. Hal tersebut dilakukan untuk mengakomodasi perkembangan zaman yang semakin maju. Nasir (2015)

Gerakan integrasi ilmu ini juga telah dikembangkan para pemikir Islam Indonesia melalui pemikiran-pemikiran individual maupun kelembagaan. Hadirnya Universitas Islam Negeri di sejumlah daerah juga mencerminkan kuatnya upaya integrasi ilmu di Indonesia.Sehingga dalam konteks ini, kurikulum yang memadukan sains dan Islam harus terus digalakkan untuk menciptakan sebuah model kurikulum yang lebih aplikatif di dalam lembaga pendidikan formal tanpa mengesampingkan kurikulum dinas yang berjalan, dengan berbagai usaha yang dapat dijalankan yaitu : (1) Kurikulum sains harus tetap berupaya mengintegrasikan antara Al-Quran, sains kealaman dan sains sosial-humaniora, (2) Konteks realitas bangsa Indonesia harus menjadi perhatian dalam melaksanakan pendidikan berparadigma kontekstual, (3) Kurikulum sains Islam harus tetap disinergikan dengan kurikulum dinas dengan menggunakan sistem SKS, (4) Diperlukan upaya pelembagaan untuk menunjang pelaksanaan kurikulum ini semisal membuat sekolah khusus sains Islam, bekerja sama dengan pihak universitas, laboratorium penelitian dan sebagainya, (5) Perlu upaya perumusan kurikulum sains Islam yang berjenjang dari sejak dini yaitu tingkat sekolah dasar, sekolah menengah pertama, sekolah menengah atas dan sampai perguruan tinggi. Ahmad (2018)

\section{Pendidikan Kurikulum Pesantren}

Pesantren telah menjadi institusi pendidikan Islam yang unik dan khas di Indonesia. Keunikan dan kekhasan menjadikan pesantren memiliki karakteristik multidimensi. Selain fungsi pendidikan juga memiliki fungsi dakwah, sosial dan budaya. Fatmawati (2015) Pesantren kini menjadi lembaga legendaris dalam sejarah pendidikan Islam di Indonesia. Eksistensi pesantren hingga saat ini menjadi bukti bahwa sistem 
pendidikan di pesantren masih diminati masyarakat. Meskipun saat ini, manajemen pesantren diarahkan pada inovasi berbagai bidang sekedar untuk memenuhi tantangan dan kebutuhan masyarakat.

Secara umum, jenis pondok pesantren bisa dikategorikan kedalam bentuk salafiyah dan khalafiyah. Meskipun demikian, realitas di lapangan tidak menunjukkan bentuk yang ekstrim. Sebagian besar yang ada sekarang adalah pondok pesantren yang berada di antara dua pengertian diatas. Sebagian pondok pesantren yang mengaku salafiyah pada umumnya juga menyelenggarakan pendidikan secara klasikal dan berjenjang, meskipun tidak dengan nama madrasah atau sekolah. Begitu juga pesantren khalafiyah pada umumnya juga menyelenggarakan pendidikan dengan pengajian kitab klasik, karena sistem ngaji kitab diakui sebagai salah satu identitas pondok pesantren. Hal ini menyebabkan kurikulum yang ada di dalamnya merupakan gabungan antara kurikulum nasional dengan pesantren. Ahmad (2015)

Secara historis, keberadaan pesantren telah membangun tradisi pendidikan yang khas bahkan telah berjalan lintas generasi. Tradisi pesantren cenderung dimaknai sebagai sisten nilai yang harus dijaga keutuhannya. Baddrut (2015) Terbentuknya tradisi pesantren tidak terlepas dari tekad para pendirinya dalam mendakwahkan Islam di Indonesia. Sentuhan spiritual inilah yang menjadi modalitas pesantren menjadi tetap eksis di tengah masyarakat. Ikatan kuat pendidikan pesantren tidak hanya dibangun melalui mata pelajaran, tetapi dibangun dengan spirit ideologis berbasis nilai dan ajaran agama.

Pendidikan pesantren akhirnya menjadi alternatif konsep pendidikan dalam sejarah perkembangan pendidikan, terutama di Indonesia. Hal ini disebabkan pesantren memberikan pendidikan holistik dan komprehensif, baik dari sisi isi kurikulum maupun proses pendidikannya. Binti (2005) Keseimbangan penguatan sikap, pengetahuan, dan keterampilan seakan telah mampu menjawab kebutuhan masyarakat terhadap pendidikan. Nilai agama yang kuat menjadi magnet tersendiri bagi orang tua untuk menyekolahkan anaknya di lembaga berbasis pesantren. Hadirnya pesantren bertujuan memberi respon terhadap situasi dan kondisi sosial di masyarakat yang dihadapkan pada ancaman runtuhnya sendi moral. Penguatan pendidikan agama melalui kitab-kitab klasik dalam berbahasa Arab menjadi bagian penting dalam menanamkan moral baik dalam diri santri.

Di sisi lain, masyarakat pesantren memiliki kepekaan yang seimbang dalam melihat keluar dan melihat ke dalam diri sendiri dikarenakan konsep yang mempertemukan antara tekstulisme fikih dengan mistisisme Islam yang dirangkai dalam form tasawuf dan tarekat. Selain itu, konsep taubat, tazkiyat al-nafs, serta nilai kontemplasi lain lebih mendrong seseorang untuk melakukan introspeksi diri dibanding melakukan penilaian terhadap orang lain. Sama halnya dengan konsep dakwah itu sendiri, dimana nilai-nilai dakwah pada hakikatnya mengajak orang lain untuk kembali kepada jalan yang haq, dan bukan untuk melakukan penilaian dan penghakiman kepada orang lain. Jika konsep ini dapat diterapkan secara utuh, maka akan tercipta suatu masyarakat yang hidup rukun dan damai berdasarkan kepercayaan beragama. Iksan (2018)

Selain itu, tujuan pesantren adalah untuk menjadi lembaga dakwah Islam dalam menyebarluaskan agama Allah. Pesantren menjadi tempat pendidikan aqidah, fiqih, Al-Qur'an serta doktrinasi agama melalui berbagai bentuk kegiatan. Ditinjau dari aspek kurikulum, pesantren diberi kebebasan oleh pemerintah untuk merencanakan, mengelola, serta mengevaluasi kurikulum yang diterapkan. Pemerintah melalui Kementerian Agama sebatas mengkoordinasi dan memberikan pembinaan untuk aspek tertantu. Kurikulum yang disusun oleh pondok pesantren, selain lebih fokus kepada kajian kitab-kitab kuning dan tradisi-tradisi kepesantrenen dengan tujuan untuk menjaga, memelihara dan mempertahankan ciri khas dan karakteristik pondok pesantren sebagi lembaga pendidikan tafaqquh fi al-din, juga lebih fokus kepada pengembangan budaya lokal dan keterampilan hidup (life skills) dengan tujuan untuk memenuhi harapan dan tuntutan kebutuhan masyarakat. Muin (2012)

Secara umum kurikulum pesantren dapat dibedakan menjadi empat bentuk, yaitu: (1) pendidikan agama, (2) pengalaman dan pendidikan moral, (3) sekolah dan pendidikan umum, dan (4) keterampilan dan kursus. Keempat muatan kurikulum pesantren inilah yang dapat disinkronkan dengan kurikulum madrasah yang berbasis pesantren Sebagaimana menurut Abdurrahman Wahid (Gus Dur), kurikulum pesantren selain harus kontekstual dengan kebutuhan zaman juga harus mampu merangsang daya intelektual-kritis anak didik. Bentuk kurikulum tersebut tetap harus dalam asas yang bermanfaat bagi masyarakat dan juga tidak sampai menghilangkan identitas diri pesantren sebagai lembaga pendidikan agama. Sebuah kurikulum mengajarkan agama saja, tetapi keduanya harus dalam porsi yang seimbang. 


\section{KESIMPULAN}

Menajemen kurikulum madrasah dengan kurikulum pesantren dapat menjadi alternatif konsep pengembangan kurikulum dalam system Pendidikan di Indonesia. Model kolaborasi dan integrasi kurikulum ini akan mendorong pada perwujudan Pendidikan yang mengintegrasikan ilmu agama dan ilmu umum yang selama ini belum terwujud. Integrasi kurikulum madrasah dengan kurikulum pesantren dapat dijadikan modeling dalam system Pendidikan madrasah sehingga lulusannya memiliki cirikhas keagamaan yang makin kuat. Madrasah yang selama ini mempelajari materi agama Islam tidak lagi setengah-setengah, tetapi proses dan kurikulumnya dapat diintegrasikan dengan kurikulum pesantren.

Kekuatan pesantren dalam hal penguatan ilmu agama berbasis kitab klasik, penguatan akhlak, serta penguatan lingkungan Islami dapat dimasukkan dalam kurikulum madrasah. Dengan demikian, kurikulum madrasah dan pesantren akan menjadi bagian yang tidak terpisahkan. Manajemen kurikulum integrasi ini perlu diawali dari perencanaan, pelaksanaan dan evaluasi kurikulum madrasah dan pesantren agar dapat dilakukan pengembangan kurikulum yang integratif. Hal ini penting dilakukan untuk mengakselerasi integrasi keilmuan, penguatan kompetensi lulusan dalam bidang agama, serta menegaskan cirikhas Pendidikan Islam.

\section{REFERENCES}

Abd. Muin M., Upaya Peningkatan Mutu Pendidikan di Pondok Pesantren $\mathrm{Hj}$. Haniah Maros Sulawesi Selatan, Edukasi, Volume 10 No. 2 Tahun 2012, hal 249

Abdullah Aly, Pendidikan Islam Multikultural di Pesantren, (Yogyakarta: Pustaka Pelajar, 2011), 184.

Abdullah, Kurikulum Pesantren dalam Perspektif Gus Dur; Suatu Kajian Epistemologis, Jurnal Pendidikan Agama Islam, Volume 4 No. 2 Tahun 2016, hal. 246

Abdullah, M. Amin. Islamic Studies Di Perguruan Tinggi: Pendekatan IntegratifInterkonektif, Cet.I, (Yogyakarta: Penerbit Pustaka Pelajar, 2006), hal 98.

Ahmad Muttaqin, Konstruksi Kurikkulum Sains Islam Keindonesiaan, Edukasi: Jurnal Penelitian Pendidikan Agama dan Keagamaan, Volume 16 No.1 Tahun 2018, hal. 92

Ahmad Saifuddin, Eksistensi Kurikulum Pesantren dan Kebijakan Pendidikan, Jurnal Pendidikan Agama Islam, Volume 3 No.1 Tahun 2015, hal. 232-233

Azra, Azyumardi. Reintegrasi Ilmu-Ilmu,Integrasi Ilmu dan Agama, Interprestasi dan Aksi, (Bandung: Mizan, 2005), hal 87.

Baddrut Tamam, Pesantrean Nalar dan Tradisi, (Yogyakarta: Pustaka Pelajar, 2015), 44

Binti Maunah, Tradisi Intelaktual Santri, (Yogyakarta: Teras, 2005), 22

Burhanuddin, "Manajemen Pendidikan: Konsep dan Penerapannya", Dalam Burhanuddin et.al. (Eds). Manajemen Pendidikan: Wacana, Proses, dan Aplikasinya di Sekolah, (Malang: Penerbit Universitas Negeri Malang, 2002), hal. 4

Erma Fatmawati, Profil Pesantren Mahasiswa,(Yogyakarta:LkiS, 2015), xiii

Hilda Taba, Curriculum development : theory and practice, (New York : Harcourt Brace Jovanovich, 1962), hal. 89.

Husniyatus Salamah Zainiyati, Desain Pengembangan Kurikulum Integratif, Nadwa: Jurnal Pendidikan Islam, Volume 8 No. 2 Tahun 2014, hal. 309

Huzni Thoyyar, www.ditpertais.net, diakses tanggal 28 Oktober 2014.

Iksan Kamil Sahri, Ideologi Damai Kaum Santri, Jurnal Pendidikan Agama Islam, Volume 6 No. 1 Tahun 2018, hal 103

Marno, Manajemen dan Kepemimpinan Pendidikan Islam, ( Bandung, Refika Aditama, 2008), hlm 90.

Muhammad Nasir, Kurikulum Madrasah: Studi Perbandingan Madrasah Di Asia, Nadwa: Jurnal Pendidikan Islam, Volume 9 No. 2 Tahun 2015, hal. 164

Sudarsono, Upaya Manajerial Pengembangan Kurikulum Program Unggulan di Madrasah Aliyah, Jurnal Pendidikan Agama Islam, Volume 4 No. 1 Tahun 2016, hal.113

Suhertian, Dimensi-dimensi Administrasi Pendidikan di Sekolah, (Surabaya: Usaha Nasional, 1985), hal. 5

Sumarni, Evaluasi Implementasi Kurikulum 2013 di Madrasah, Edukasi: Jurnal Penelitian Pendidikan Agama dan Keagamaan, Volume 15 No. 3 Tahun 2017, hal 410

Syaekhuddin, http:// wordpress.com/2009, Menuju-integrasi-ilmu-ilmukeislaman-dengan-ilmu-ilmu-umum, diakses tanggal 27 Oktober 2014.

Conflict of Interest Statement: The authors declare that the research was conducted in the absence of any commercial or financial relationships that could be construed as a potential conflict of interest.

Copyright $@ 2021$ M. Islam. This is an open-access article

distributed under the terms of the Creative Commons Attribution License (CC BY). The use, distribution or reproduction in other forums is permitted, provided theoriginal author(s) and the copyrightowner(s) arecredited and that theoriginal publication in this journal is cited, in accordance with accepted academic practice. No use, distribution or reproduction is permitted which does not comply with these terms. 


\section{LIST OF TABLES}

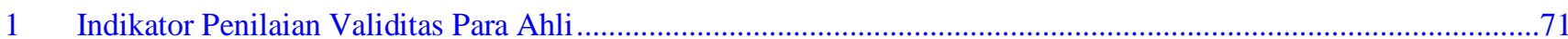


TABLE 1/Model Integrasi IImu dalam Perspektif Cendekiawan Islam

MODEL INTEGRASI

IFIAS (International Federation of Institutes of Advance Study) dikembangkan tahun 1984

Akademi Sains Islam Malaysia (ASASI) dikembangkan tahun 1977

Islamic Worldview Dikembangkan di Turki

\section{KONSEP INTEGRASI}

Dalam Islam, tidak ada pemisahan antara sarana dan tujuan sains. Keduanya tunduk pada tolok ukur etika dan nilai keimanan. la harus mengikuti prinsip bahwa sebagai ilmuwan yang harus mempertanggungjawabkan seluruh aktivitasnya pada Tuhan, maka ia harus menunaikan fungs sosial sains untuk melayani masyarakat, dan dalam waktu yang bersamaan melindungi dan meningkatkan institusi etika dan moralnya. Dengan demikian, pendekatan Islam pada sains dibangun di atas landasan moral dan etika yang absolut dengan sebuah bangunan yang dinamis berdiri di atasnya. Akal dan objektivitas dianjurkan dalam rangka menggali ilmu pengetahuan ilmiah, di samping menempatkan upaya intelektual dalam batas-batas etika dan nilai-nilai Islam

Model ASAI ini berpandangan bahwa ilmu tidak terpisah dari prinsip-prinsip Islam. Model ASASI ingin mendukung dan mendorong pelibatan nilai- nilai dan ajaran Islam dalam kegiatan penelitian ilmiah; menggalakkan kajian keilmuan di kalangan masyarakat; dan menjadikan Alquran sebagai sumber inspirasi dan petunjuk serta rujukan dalam kegiatan-kegiatan keilmuan. ASASI mendukung cita-cita untuk mengembalikan bahasa Arab, selaku bahasa Alquran, kepada kedudukannya yang hak dan asli sebagai bahasa ilmu bagi seluruh Dunia Islam, dan berusaha menyatukan ilmuwanilmuwan Muslim ke arah memajukan masyarakat Islam dalam bidang sains dan teknologi.

Model ini berawal dari pandangan dunia Islam (Islamic worldview) bahwa wahyu merupakan dasar bagi epistemoligi keilmuan Islam secara menyeluruh dan integral. Dua pemikir Muslim yang secara intens menggagas dan mengembangkan model ini adalah Alparslan Acikgenc, Tenaga pendidik Besar Filsafat pada Fatih University, Istanbul Turki. la mengembangkan empat pandangan dunia Islam sebagai kerangka komprehensif keilmuan Islam, yaitu: (1) iman sebagai dasar struktur dunia (world structure, îmân); (2) ilmu sebagai struktur pengetahuan (knowledge structure, al-'ilm); (3) fikih sebagai struktur nilai (value structure, al-figh); dan (4) kekhalifahan sebagai struktur manusia (human structure, khalîfah

Struktur Pengetahuan Islam (SPI) ( Dalam konsep ini, ilmu secara sistematik telah diorganisasikan dalam berbagai disiplin akademik yang mengembangkan hubungan yang komprehensif antara ilmu dan agama. Hal ini hanya mungkin dilakukan jika umat Islam mengakui kenyataan bahwa pengetahuan (knowledge) secara sistematik telah diorganisasikan dan dibagi ke dalam sejumlah disiplin akademik. Keempat stryktur pengetahuan itu adalah: (1) komponen pertama berkenaan dengan apa yang disebut dengan subjek dan objek matter ilmu yang membangun tubuh pengetahuan dalam bentuk konsep (concepts), fakta (facts, data), teori (theories), dan hukum atau kaidah ilmu (laws), serta hubungan logis yang ada padanya; (2) komponen kedua terdiri dari premis-premis dan asumsi-asumsi dasar yang menjadi dasar epistemologi keilmuan; (3) komponen ketiga berkenaan dengan metode-metode pengembangan ilmu; dan (4) komponen terakhir berkenaan dengan tujuan yang ingin dicapai oleh ilmu.

Model Bucaillisme

Model ini bertujuan mencari kesesuaian penemuan ilmiah dengan ayat Alquran. Dalam konsep ini, Alquran dianggap sesuai dengan sesuatu yang masih bisa berubah berarti menganggap Alquran juga bisa berubah. Model ini di kalangan ilmuwan Muslim Malaysia biasa disebut dengan "Model Remeh" karena sama sekali tidak mengindahkan sifat kenisbian dan kefanaan penemuan dan teori sains Barat dibanding dengan sifat mutlak dan abadi Alquran. Penemuan dan teori sains Barat berubah-ubah mengikut perubahan paradigma, contohnya dari paradigma klasik Newton yang kemudian berubah menjadi paradigma quantum Planck dan kenisbian Einstein. Model ini mendapa kritik tajam karena, apabila Ayat Alquran dinyatakan sebagai bukti kebenaran suatu teori dan teori tersebut mengalami perubahan, maka kewibawaan Alquran akan rusak karena membuktikan teori yang salah mengikuti paradigma baru ini.

Model Integrasi Keilmuan Berbasis Filsafat Klasik

Integrasi Keilmuan Berbasis Filsafat Klasik berusaha menggali warisan filsafat Islam klasik. Tokoh utama model ini adalah Seyyed Hossein Nasr. Dalam konsep ini Tawhîd dimasukkan dalam skema teori. model ini juga yakin bahwa alam tabi'i hanyalah merupakan tanda atau ayat bagi adanya wujud dan kebenaran yang mutlak. Hanya Allah-lah Kebenaran sebenar- benarnya, dan alam tabi'i in hanyalah merupakan wilayah kebenaran terbawah. Bagi Seyyed Hossein Nasr, ilmuwan Islam moden hendaklah mengimbangi dua pandangan tanzîh dan tasybîh untuk mencapai tujuan integrasi keilmuan ke-Islaman.

Model Integrasi Berbasis Tasawuf

Tokoh model ini adalah Syed Muhammad Naquib al-Attas. Konsep integrasi dalam model ini juga dikenal dengan konsep Islamisasi IImu Pengetahuan (Islamization of Knowledge). Gagasan in pertama kali muncul pada saat konferendi Makkah, di mana pada saat itu, Al-Attas mengimbau dan menjelaskan gagasan "Islamisasi Ilmu Pengetahuan". Hal ini berawal dari adanya krisis epistemologi umat Islam sekaligus formulasi jawabannya dalam bentuk Islamisasi ilmu pengetahuan masa kini yang secara filosofis berkaitan, benar-benar merupakan prestasi inovatif dalam pemikiran Islam modern. Formulasi awal dan sistematis ini merupakan bagian integral dan konsepsinya mengenai pendidikan dan universitas Islam serta kandungan dan metode umumnya. Karena kebaruan ide-ide yang dipresentasikan dalam kertas kerjanya di Makkah, tema-tema gagasan ini diulas kembali dan dijelaskan panjang lebar pada Konferensi Dunia yang Kedua mengenai Pendidikan Umat Islam pada 1980 di Islamabad.

Model Integrasi Berbasis IImu Fiqih

Model ini digagas oleh Ismail Raji al-Faruqi. Dalam model ini perlu dilakukan Islamisasi IImu Pengetahuan dengan berangkat dari pemikiran ulama fiqh dalam menjadikan Alquran dan Assunnah sebagai puncak kebenaran. Kaidah fiqh ialah kaedah penentuan hukum fiqh dalam ibadah yang dirumuskan oleh para ahli figh Islam melalui deduksi Alquran dan keseluruhan korpus al-Hadith Pendekatan ini sama sekali tidak menggunakan warisan sains Islam yang dipelopori oleh Ibn Sina, al-Biruni dan sebagainya. Bagi al-Faruqi, "sains Islam" seperti itu tidak Islami karena tidak bersumber dari teks Alquran dan Hadits.

Model Integrasi ljmaili Tokoh model ini adalah Ziauddin Sardar. Menurut model ini tujuan sains Islam bukan untuk mencari kebenaran akan tetapi melakukan penyelidikan sains menurut kehendak masyarakat Muslim berdasarkan etos Islam yang digali dari Alquran. Sains adalah sarat nilai (value bounded) dan kegiatan sains lazim dijalankan dalam suasana pemikiran atau paradigma tertentu. Pandangan ini mengikuti konsep paradigma ilmu Thomas Kuhn. Model ini juga menggunakan konsep 'adl dan zulm sebagai kriterium untuk menentukan bidang sains yang perlu dikaji dan dilaksanakan. Pandangan ini menerima semua penemuan sains Barat modern dan hanya prihatin terhadap sistem nilai atau etos yang mendasari sains tersebut. Dengan menggunakan beberapa istilah dari Alquran seperti Tawhîd, 'ibadah, khilafah, halal, haram, taqwa, 'ilm dan istislah. Konsep-konsep yang dikemukakan model ini tidak merujuk pada tradisi sains Islam klasik. 
Model Kelompok Aligargh
Model ini dipelopori oleh Zaki Kirmani dari University India. Model ini menyatakan bahwa sains Islam berkembang dalam suasana 'ilm dan tasykir untuk menghasilkan gabungan ilmu dan etika. Pendek kata, sains Islam adalah sekaligus sains dan etika. Model penelitian berdasarkan berdasarkan wahyu dan taqwa. la juga mengembangkan struktur sains Islam dengan menggunakan konsep paradigma Thomas Kuhn. Kirmani kemudian menggagas makroparadigma mutlak, mikroparadigma mutlak, dan paradigma bayangan. 